\title{
Bladder Cancer pT2a TNM Finding v7
}

National Cancer Institute

\section{Source}

National Cancer Institute. Bladder Cancer pT2a TNM Finding v7. NCI Thesaurus. Code C89353.

Bladder cancer with tumor invading the superficial muscularis propria (inner half). (from AJCC 7th Ed.) 